\title{
Quantification of aluminum and heavy metal contents in cooked rice samples from Thailand markets using inductively coupled plasma mass spectrometry (ICP-MS) and potential health risk assessment
}

\author{
Anawat Rittirong' and Kiadtisak Saenboonruang ${ }^{1}$ * \\ ${ }^{1}$ Department of Applied Radiation and Isotopes, Faculty of Science, Kasetsart University, Bangkok, 10900, Thailand
}

\section{A B S T R A C T}

\begin{abstract}
This work quantified contents of $\mathrm{Al}$ and heavy metals, namely $\mathrm{Cr}, \mathrm{Fe}, \mathrm{Cu}, \mathrm{Zn}, \mathrm{As}, \mathrm{Cd}$, and $\mathrm{Pb}$, in cooked rice samples prepared using five different cooking utensils (new and used Al cookers, a Teflon-coated Al cooker, a stainless steel cooker, and a glass beaker) and four different water conditions (tap water, de-ionized water, acidic water, and basic water) in order to assess metal leaching from cooking utensils and potential health risks to local consumers. The result showed that Al contents $\left(76.50 \mathrm{mg} \mathrm{kg}^{-1} \mathrm{in}\right.$ raw rice and $76.83 \mathrm{mg} \mathrm{kg}^{-1}$ in cooked rice samples) and $\mathrm{Zn}$ contents $\left(22.86 \mathrm{mg} \mathrm{kg}^{-1}\right.$ in raw rice and $22.43 \mathrm{mg} \mathrm{kg}^{-1}$ in cooked rice samples) represented the two largest contents of tested elements, in which contents of $\mathrm{Al}>\mathrm{Zn}>\mathrm{Fe}>\mathrm{Pb} \approx \mathrm{Cu}>\mathrm{Cr}>\mathrm{As} \approx \mathrm{Cd}$. However, no strong indication of substantial metal leaching from cooking utensils to cooked rice were observed in this work as the metal contents in cooked rice samples did not significantly differ from raw rice grains $(p<0.05)$. The result also indicated that the estimated weekly intake of $\mathrm{Al}$ and $\mathrm{Pb}$ associated with rice consumption of a person who consumed approximately $0.3 \mathrm{~kg}$ of rice per day (181.07 mg $\mathrm{kg}^{-1}$ week $^{-1}$ and $4.85 \mathrm{mg} \mathrm{kg}^{-1}$ week ${ }^{-1}$, respectively) was greater than the provisional tolerance weekly intake (PTWI) recommended by the joint FAO/WHO committee for a person who weighs $60 \mathrm{~kg}\left(120 \mathrm{mg} \mathrm{kg}^{-1}\right.$ week $^{-1}$ and $1.5 \mathrm{mg} \mathrm{kg}^{-1}$ week ${ }^{-1}$, respectively). In terms of the assessment of non-carcinogenic and carcinogenic health risks, the hazard index $(H /)$ calculated from all concerned metals was 9.18, with the largest contributions from $\mathrm{Pb}$ (3.19), As (2.67), and Al (1.51), indicating a potential non-carcinogenic risk, while the total cancer risk (CRt) was $2.45 \times 10^{-2}$, with the largest contributions from $\mathrm{Pb}\left(1.0 \times 10^{-2}\right)$ and $\mathrm{Cd}\left(1.2 \times 10^{-2}\right)$, indicating serious carcinogenic risks to local consumers.
\end{abstract}

Keywords: Aluminum; Food safety; Health risks; Heavy metal; ICP-MS; Rice

\section{INTRODUCTION}

Rice (Oryza sativa) is one of the most consumed foods in the world, especially in southern and eastern Asia, due to its abundant nutrients and favorable taste. It was estimated that Asia's per capita rice consumption had increased from $85 \mathrm{~kg}$ per year in the early ' 60 s to $103 \mathrm{~kg}$ per year in the early ' $90 \mathrm{~s}$, while the global per capita consumption rose from 50 to $65 \mathrm{~kg}$ per year during the same period. Furthermore, rice consumption and production are anticipated to keep growing due to the rapid increase in the world's population, improved nutrition in rice, and better harvesting technologies (Mohanty, 2013).
Rice grains have a high carbohydrates content, with small amounts of protein and fat, making them one of the most important sources of energy and nutrition for humankind. Rice also contains many useful substances including Omega-3 and Omega- 6 fatty acids that are important components of cell membranes that help to regulate blood pressure and inflammatory response. However, elements such as aluminum $(\mathrm{Al})$ and heavy metals (arsenic: As, cadmium: $\mathrm{Cd}$, iron: $\mathrm{Fe}$, lead: $\mathrm{Pb}$, zinc: $\mathrm{Zn}$, copper: $\mathrm{Cu}$, and chromium: $\mathrm{Cr}$ ) in rice grains could pose a serious health risk to consumers.

In the case of $\mathrm{Al}$, which is the third most abundant element in the earth's crust, several medical reports

\footnotetext{
${ }^{*}$ Corresponding author:

Kiadtisak Saenboonruang, Department of Applied Radiation and Isotopes, Faculty of Science, Kasetsart University, Bangkok, 10900,

Thailand, E-mail: fscikssa@ku.ac.th
} 
have linked its excessive daily intake to possible causes of brain, blood, and bones diseases (Al Zubaidy et al., 2011), especially Alzheimer's disease, for which it has been reported that residual aluminum in drinking water plays an important role in developing the disease (Becaria et al., 2006; McLachlan et al., 1996; Flaten, 2001; Crapper et al., 1966). In raw rice, the $\mathrm{Al}$ content was measured to be from as little as a few $\mathrm{mg} \mathrm{kg}^{-1}$ up to $350 \mathrm{mg} \mathrm{kg}^{-1}$ depending on the rice type, growing region, and measurement method (Semwal et al., 2006; Odularu et al., 2013). The World Health Organization (WHO) reported in 1989 that the provisional tolerance weekly intake (PTWI) of $\mathrm{Al}$ was not more than $7 \mathrm{mg} \mathrm{kg}^{-1}$ of body weight (World Health Organization, 1989) and later this was revised to $1 \mathrm{mg}$ $\mathrm{kg}^{-1}$ of body weight and $2 \mathrm{mg} \mathrm{kg}^{-1}$ of body weight in 2006 and 2011, respectively (Center for Food Safety, 2009; World Health Organization, 2011). This means that a person weighing $60 \mathrm{~kg}$ could have a maximum $\mathrm{Al}$ intake of $120 \mathrm{mg}$ per week according to the WHO report. As a consequence, from previous reports, a moderate person who consumes roughly 1-2 kg of rice per week could be at a serious health risk of excessive aluminum intake, with even greater effects for people living in southern and eastern Asia.

In addition to the risks from $\mathrm{Al}$ intake, heavy metals such as $\mathrm{As}, \mathrm{Cd}, \mathrm{Fe}, \mathrm{Pb}, \mathrm{Zn}, \mathrm{Cu}$, and $\mathrm{Cr}$ are also posing threats to consumer's health. Table 1 shows the possible health effects of these heavy metals, for both acute and chronic exposures, and the PTWI of each element recommended by the joint FAO/WHO committee. Zeng et al. (2015) used atomic absorption spectrometry (AAS) to show that raw brown rice in Hunan Province, China, contained $\mathrm{Cd}$ $\left(0.325 \mathrm{mg} \mathrm{kg}^{-1}\right)$, Cr $\left(0.109 \mathrm{mg} \mathrm{kg}^{-1}\right)$, As $\left(0.344 \mathrm{mg} \mathrm{kg}^{-1}\right)$, $\mathrm{Ni}\left(0.610 \mathrm{mg} \mathrm{kg}^{-1}\right), \mathrm{Mn}\left(9.03 \mathrm{mg} \mathrm{kg}^{-1}\right), \mathrm{Pb}\left(0.023 \mathrm{mg} \mathrm{kg}^{-1}\right)$, and $\mathrm{Hg}\left(0.071 \mathrm{mg} \mathrm{kg}^{-1}\right)$, which indicated that long-term exposure to heavy metals through brown rice consumption posed both potential non-carcinogenic and carcinogenic health risks to the local residents.

In addition to health risks from $\mathrm{Al}$ and heavy metals intake from rice grains, possible leaching from cooking utensils, especially rice cookers, could potentially add more metals to raw rice and pose greater health effects. This possibility of leaching has led to several attempts to clarify the safety of rice cookers. Odularu et al. (2013) investigated possible leaching of $\mathrm{Al}$ from aluminum, clay, stainless steel, and steel cooking pots using colorimetry and the aluminon method at $550 \mathrm{~nm}$. The results showed that rice cooked in an aluminum pot had the content of $\mathrm{Al}$ ranging from $126 \mathrm{mg} \mathrm{kg}^{-1}$ to $314 \mathrm{mg} \mathrm{kg}^{-1}$. Another study using a UV spectrometer and the aluminon method at $530 \mathrm{~nm}$ performed by Amarasooriya et al. (2014) indicated that rice cooked in the presence of aluminum plate without fluoride water resulted in an additional $6.5 \mathrm{mg} \mathrm{kg}^{-1}$ of $\mathrm{Al}$ in rice and the $\mathrm{Al}$ contents increased as the fluoride concentration in the water increased. This possible leaching of $\mathrm{Al}$ could affect consumers' health as shown by Ileperuma et al. (2009) that the dissolution of $\mathrm{Al}$ from utensils under high fluoride stress could be a possible risk factor for chronic renal failure in the North-Central Province in Sri Lanka. On the other hand, Omar et al. (2015) investigated the bioavailability of heavy metals in cooked rice using an in vitro digestion model and inductively coupled plasma optical emission spectrometry (ICP-OES). The results indicated that cooked rice contained $\mathrm{Cr}\left(0.11 \pm 0.01 \mathrm{mg} \mathrm{kg}^{-1}\right), \mathrm{Cd}$ $\left(0.031 \pm 0.001 \mathrm{mg} \mathrm{kg}^{-1}\right), \mathrm{Cu}\left(1.1 \pm 0.1 \mathrm{mg} \mathrm{kg}^{-1}\right), \mathrm{Fe}$ $\left(1.9 \pm 0.1 \mathrm{mg} \mathrm{kg}^{-1}\right)$, and $\mathrm{Zn}\left(4.3 \pm 0.1 \mathrm{mg} \mathrm{kg}^{-1}\right)$, leading to high cancer risks for both adults and children.

Table 1: Possible health effects of heavy metals and their PTWI levels recommended by the WHO. (World Health Organization, 2011; Occupational Safety and Health Administration, 2013). Numbers in parentheses represent PTWI values before the limits were withdrawn

\begin{tabular}{|c|c|c|}
\hline Element & Health effects & $\begin{array}{l}\text { Provisional tolerance weekly intake (PTWI) } \\
\text { ( } \mathrm{mg} \mathrm{kg}^{-1} \text { of body weight) }\end{array}$ \\
\hline Arsenic (As) & $\begin{array}{l}\text { Discoloration of the skin, appearance of small corns or warts, and } \\
\text { death. }\end{array}$ & $(0.0147)^{\mathrm{a}}$ \\
\hline Cadmium (Cd) & Flu-like symptoms, kidney, bone, and lung disease. & 0.006 \\
\hline Iron $(\mathrm{Fe})$ & $\begin{array}{l}\text { Irritant to the lungs and gastrointestinal tract, siderosis, and interstitial } \\
\text { disease. }\end{array}$ & 5.6 \\
\hline Lead $(\mathrm{Pb})$ & $\begin{array}{l}\text { Impaired kidney function, high blood pressure, nervous system and } \\
\text { neurobehavioral effects, subtle cognitive effects attributed to prenatal } \\
\text { exposure. }\end{array}$ & $(0.025)^{b}$ \\
\hline Zinc $(Z n)$ & Copper deficiency and dermatitis following prolonged skin exposure. & 2.1-7.0 \\
\hline Copper (Cu) & Cumulative lung damage. & 3.5 \\
\hline Chromium (Cr) & $\begin{array}{l}\text { Cancer and damage to respiratory system, kidneys, liver, skin, and } \\
\text { eyes. }\end{array}$ & 0.0233 \\
\hline
\end{tabular}


Despite the availability of information on $\mathrm{Al}$ and heavy metal contents in rice samples, previous methods used for the analysis could have disadvantages that led to inaccurate results and difficult interpretation. For example, similar wavelengths of light emitted from different elements or matrix interferences could affect analysis in the colorimetry method. To overcome these constrains, inductively coupled plasma mass spectrometry (ICP-MS), which has equal or better detection limits for most elements than AAS, colorimetry, and ICP-OES, with simultaneous multi-element measurement ability, was selected as an analytical tool in this work (Horn, 2000; Whitea, 2000). Another important justification of this work was that, in contrast to $\mathrm{Al}$, information of heavy metal leaching from cooking utensils during rice cooking was lacking and insufficient as seen by a small number of heavy metal species and reports. An example of heavy metal leaching study was the measurement of $\mathrm{Ni}$ and $\mathrm{Cr}$ leaching from a stainless steel pot into tomato sauces, which showed slight increases in $\mathrm{Ni}$ and $\mathrm{Cr}$ contents after cooking (Kamerud, 2013).

As a result, we aimed to quantify the $\mathrm{Al}$ and heavy metal $(\mathrm{Cr}, \mathrm{Fe}, \mathrm{Cu}, \mathrm{Zn}, \mathrm{As}, \mathrm{Cd}$, and $\mathrm{Pb}$ ) contents using ICP-MS in both raw rice and cooked rice samples that were prepared using five different rice cooking utensils (new and 3-yearold Al cookers, a Teflon-coated Al cooker, a stainless steel cooker, and a laboratory glass beaker) and four different water conditions (tap water, de-ionized water, acidic water, and basic water). The contents of all concerned metals obtained from the measurement were then analyzed in order to assess any significant level of metal leaching and any potential health risk to local consumers. Overall results from this work would be greatly useful for both policymakers, producers, and consumers to raise food safety awareness associated with rice consumption.

\section{MATERIALS AND METHODS}

\section{Instruments and apparatus}

An electrically heated oven (Binder: Model ED/FD, USA) ventilated naturally and by fan-assisted circulation and a laboratory agate gyro mill (Glen Creston, USA) were used for sample milling and digestion. Rice samples were cooked using four 1-L commercial rice cooking utensils that were made from different materials-new and 3-year-old $\mathrm{Al}$ (New-Al and Old-Al, respectively), Teflon-coated Al (Tef-Al), stainless steel (SS) —and one reference cooker (a laboratory glass beaker; Gl). It should be noted that all cooking utensils were cleaned by distilled water and a commercial dishwasher and left to dry in an open air. The powdered rice samples were kept in sealed polyethylene (PE) bags at $-16^{\circ} \mathrm{C}$ using a medical refrigerator (EVERMed: Model LCDF 220 W, Italy), while the rice samples in solvents prepared for ICP-MS analysis were stored in highdensity polyethylene bottles. Table 2 shows the operating parameters of the ICP-MS machine and settings used for the elemental analysis. The detection limits for all concerned elements were $20 \mathrm{ng} \mathrm{L}^{-1}$ except for Fe that had a detection limit of $900 \mathrm{ng} \mathrm{\textrm {L } ^ { - 1 }}$.

\section{Reagents}

All reagents including $\mathrm{HNO}_{3}, \mathrm{HCl}$, and $\mathrm{NaOH}$ (Merck Millipore, Thailand) for sample digestion and water preparation were of analytical-reagent grade. The water used in this work, unless note otherwise, was doubly deionized using a Milli-Q water purification system (Millipore, USA). Plastic materials were cleaned by soaking in 10\% (v/v) $\mathrm{HNO}_{3}$ for $24 \mathrm{hr}$, rinsing with de-ionized water and dry under a class 100 laminar flow hood, which was also used during sample digestion.

\section{Sample preparation}

Three different brands of white rice grown in central Thailand were purchased in a local grocery store in Bangkok. Four types of water-regular tap water (TW), de-ionized water (DW), acidic water (AW) and basic water (BW) were used to cook rice samples. For TW, normal running water in households supplied by the Thailand Metropolitan Waterworks Authority (MWA) was used. For AW, $1 \mathrm{~mL}$ of $6 \mathrm{M} \mathrm{HCl}$ was mixed with $200 \mathrm{~mL}$ of DW and continuously stirred in a $250 \mathrm{~mL}$ laboratory beaker. Then, $3.35 \mathrm{~mL}$ of the strong acidic solution was transferred and diluted with $\mathrm{DW}$ in a $1000 \mathrm{~mL}$ measuring cylinder

Table 2: ICP-MS machine model (Agilent 7500a and 7500c) and operating parameter settings

\begin{tabular}{ll}
\hline Operating parameter & Setting \\
\hline Spray chamber type & Scott double pass, $2 \pm 0.1^{\circ} \mathrm{C}$ \\
Nebulizer type & Babbington high solids nebulizer \\
RF power $(\mathrm{W})$ & $1350 \mathrm{~W}(7500 \mathrm{a}), 1500 \mathrm{~W}(7500 \mathrm{c})$ \\
Carrier gas flow rate $\left(\mathrm{L} \mathrm{min}^{-1}\right)$ & 1.08 \\
Make-up gas flow rate $\left(\mathrm{L} \mathrm{min}^{-1}\right)$ & 0.00 \\
Data acquisition mode & Spectrum analysis mode and full quant mode \\
Torch & Fassel \\
Sample depth & $7.0 \mathrm{~mm}$ \\
Integration time $(\mathrm{ms})$ & $300 \mathrm{for} \mathrm{As,} \mathrm{Zn}, \mathrm{Cr}$, and $\mathrm{Al}$ and $100 \mathrm{for} \mathrm{Fe}, \mathrm{Cd}, \mathrm{Cu}$, and $\mathrm{Pb}$ \\
\hline
\end{tabular}


until the $\mathrm{pH}$ of the $\mathrm{AW}$ was approximately $4.0 \pm 0.3$. For BW, $0.4 \mathrm{~g}$ of $\mathrm{NaOH}$ was mixed with DW and stirred in a $1000 \mathrm{~mL}$ measuring cylinder until the $\mathrm{pH}$ of the $\mathrm{BW}$ was approximately $10.0 \pm 0.3$. To determine whether the water used during rice cooking could contribute significant amounts of $\mathrm{Al}$ and heavy metals to the rice samples, $5 \mathrm{~mL}$ of each water type was individually analyzed using the same ICP-MS setup and procedures. The results indicated that the $\mathrm{Al}$ and heavy metal contents in all types of water were substantially less than $1 \mathrm{mg} \mathrm{kg}^{-1}$; hence, they contributed negligibly to the final elemental contents in the cooked rice samples.

To prepare cooked rice samples, all 20 possible combinations were tested using $432 \mathrm{~g}$ of each rice sample separately cooked with $600 \mathrm{~mL}$ of each water type in each of the five rice cookers. The cooked rice samples were then oven-dried at $65^{\circ} \mathrm{C}$ for $48 \mathrm{hr}$ and ground to fine powder using the laboratory agate gyro mill. The cooked rice powder samples were sealed in PE bags and kept at $-16^{\circ} \mathrm{C}$ for sample digestion. For reference purposes, raw rice grains were also oven-dried, ground, and kept in PE bags following the same procedures used for the cooked rice samples.

To perform sample digestion, powder samples weighing $0.50 \pm 0.01 \mathrm{~g}$ were added to $5 \mathrm{~mL}$ of $(65 \% \mathrm{w} / \mathrm{w}) \mathrm{HNO}_{3}$ and left for 30-40 minutes. The samples were then heated using a hot plate with a magnetic stirrer at $95^{\circ} \mathrm{C}$ for $2 \mathrm{hr}$. Another $5 \mathrm{~mL}$ of $(65 \% \mathrm{w} / \mathrm{w}) \mathrm{HNO}_{3}$ was later added to the samples and heated again at $95^{\circ} \mathrm{C}$ for $2 \mathrm{hr}$. The samples were then left to cool and the volume was made up to $50 \mathrm{~mL}$ in a volumetric flask using de-ionized water. To perform ICP-MS analysis, $5 \mathrm{~mL}$ of each digested rice sample was transferred to a measuring cylinder and tested under the settings shown in Table 2. The sample IDs used to identify rice samples under different conditions were the synonym of cooker types followed by the synonym of water types used in rice cooking. For example, a rice sample that was cooked in the 3-year-old $\mathrm{Al}$ rice cooker with DW would be noted as Old-Al-DW.

\section{Quality assurance and quality control}

The spike recovery test was performed to validate and to assess the accuracy of ICP-MS in elemental analysis. To perform the spike recovery test, an uncooked rice sample was divided into two sets and digested using the same procedures outlined in the sample preparation section. One of the two $50 \mathrm{~mL}$ rice samples was added with $1 \mathrm{~mL}$ of the environmental calibration standard (Agilent Part Number 5183-4688, USA) that contained known amounts of elements of interest $\left(20,000 \mu \mathrm{g} \mathrm{L} \mathrm{L}^{-1}\right.$ for Fe and $200 \mu \mathrm{g} \mathrm{\textrm {L } ^ { - 1 }}$ for other elements). Both spiked and unspiked samples were then analyzed using ICP-MS.
The percentages of spike recovery for each element were calculated using the equation

$\%$ Recovery $=[($ Observed - Neat $) /$ Expected $] \times 100 \%$

where Observed, Neat, and Expected are the element contents in spiked samples, the element contents in unspiked samples, and the known amount of standard that was spiked into the sample, respectively. Since the acceptable percentage of recovery depends on the concentration and species of the element of interest, the acceptable percentage of recovery in our work, in which the element contents were expected to be in the range $0.1-100 \mathrm{mg} \mathrm{kg}^{-1}$, needed to be in the range of $80-120 \%$.

The results of the spike recovery test showed that the range of the percentage recovery was between $86.17 \%-106.11 \%$, indicating sufficient accuracy of the elemental determination of ICP-MS to extract reliable and accurate information.

\section{Statistical analysis and validation of method}

A level of $95 \%$ significance $(p<0.05)$ was used for the descriptive analysis of data. The t-test was also applied to determine any significant difference between each condition of cooked rice samples.

\section{Health risk assessment}

Non-carcinogenic and carcinogenic risks from rice consumption were evaluated to characterize the health risks due to exposure to the toxicants in the cooked rice. The non-carcinogenic risk was determined using the hazard quotient $(H Q)$, which is the ratio of the potential exposure to a substance and the level at which no adverse effects are expected, and can be calculated as (Zeng et al., 2015)

$H Q=A D I / R f D$

where $A D I$ and $R f D$ are the average daily intake and the reference dose issued by the Integrated Risk Information System (IRIS), respectively (Zeng et al., 2015). If $H Q$ is less than 1 , adverse health effects would be unlikely to occur. On the other hand, if $\mathrm{HQ}$ is greater than 1, potential noncarcinogenic effects could occur (Nuapia et al., 2018). In this work, HQ was calculated based on (Zeng et al., 2015)

$A D I=C \times I R \times E D \times E F / B W \times A T$

where $C, I R, E D, E F, B W$, and $A T$ are the metal content $\left(\mathrm{mg} \mathrm{kg}^{-1}\right)$ in cooked rice, the ingestion rate $\left(\mathrm{kg} \mathrm{d}^{-1}\right)$, exposure duration (d), exposure frequency (y), body weight (kg), and average time (d) respectively. The $I R, E D, E F, B W$, and $A T$ values used in this work were $0.3 \mathrm{~kg} \mathrm{~d}^{-1}, 365 \mathrm{~d}, 75 \mathrm{y}$, $60 \mathrm{~kg}$, and 27,375 d, respectively, based on the average rice consumption rate in Thailand reported by the Office of Agricultural Economics, Thailand Ministry of Agriculture and Cooperatives, the life expectancy at birth reported by 
the World Health Organization (2015), and the average weight of Thai adults reported by Charoensitiwath (2010).

Another indication of non-carcinogenic health risk caused by a mixture of toxicants is provided by the hazard index (HI), which was calculated as (Zeng et al., 2015)

$$
\mathrm{HI}=\Sigma \mathrm{HQ}
$$

For cases where $H I>1$, chronic risks are likely to occur.

In terms of carcinogenic risks, the cancer risk $(C R)$ of a carcinogenic element, which represents the incremental probability of an individual to develop cancer over a lifetime, was evaluated as (Zeng et al., 2015)

\section{$\mathrm{CR}=\mathrm{ADIXCSF}$}

where CSF is the cancer slope factor of element of interest. In this work, only the oral intake of relevant metals would be of interest in the carcinogenic risk assessment. If multiple carcinogenic elements are present, the total cancer risk $(C R t)$ could be calculated as (Zeng et al., 2015)

$$
\mathrm{CRt}=\Sigma \mathrm{CR}
$$

$C R t$ values in the range $1.0 \times 10^{-6}$ to $1.0 \times 10^{-4}$ are considered acceptable for carcinogenic risk, while a $C R t$ value greater than $1.0 \times 10^{-4}$ indicates possible carcinogenic risk (Cao et al., 2015) The values of RfD and CSF for each element are shown in Table 3.

\section{RESULTS AND DISCUSSION}

\section{Elemental analysis in raw and cooked rice samples}

Values of elemental contents in raw and cooked rice samples are shown in Table 4 and Table 5. The results showed that $\mathrm{Al}$ and $\mathrm{Zn}$ represented the two largest contents of tested elements in both raw and cooked rice, in which the average contents of $\mathrm{Al}>\mathrm{Zn}>\mathrm{Fe}>\mathrm{Pb} \approx \mathrm{Cu}>\mathrm{Cr}$ $>\mathrm{As} \approx \mathrm{Cd}(\mathrm{p}<0.05)$.

The contents of $\mathrm{Al}$ in rice samples found in this work $\left(49.19-115.16 \mathrm{mg} \mathrm{kg}^{-1}\right)$ were in between the reported values of Odularu et al. (2013), Omar et al. (2015), and Semwal et al. (2006), in which the former report showed the $\mathrm{Al}$ contents of $126 \pm 64 \mathrm{mg} \mathrm{kg}^{-1}, 314 \pm 128 \mathrm{mg} \mathrm{kg}^{-1}$, and $295 \pm 163 \mathrm{mg} \mathrm{kg}^{-1}$ for samples cooked in a new Al cooker, a used $\mathrm{Al}$ cooker, and a SS cooker, respectively, while the latter two reports showed the $\mathrm{Al}$ contents between $0.67-1.5 \mathrm{mg} \mathrm{kg}^{-1}$. The large variations in $\mathrm{Al}$ contents found in this work and other works could be due to the differences in rice types, growing regions, and the accuracy of testing methods used to quantify $\mathrm{Al}$ contents. For heavy metal contents, the values found in this work were in agreements with the previous work of Zarcinas et al. (2004) who investigated heavy metals contents in soils and crops in Thailand. The report indicated that $\mathrm{Zn}$ had the highest contents in rice samples $\left(22.8 \mathrm{mg} \mathrm{kg}^{-1}\right)$ compared to As $\left(<1 \mathrm{mg} \mathrm{kg}^{-1}\right), \mathrm{Cd}\left(0.05 \mathrm{mg} \mathrm{kg}^{-1}\right), \mathrm{Cr}\left(0.7 \mathrm{mg} \mathrm{kg}^{-1}\right)$, $\mathrm{Cu}\left(2 \mathrm{mg} \mathrm{kg}^{-1}\right)$, and $\mathrm{Pb}\left(0.11 \mathrm{mg} \mathrm{kg}^{-1}\right)$. The results were also similar to the reports of Zeng et al. (2015), who showed that the heavy metal contents in brown rice samples cultivated in Human Province, China, had Cd $\left(0.325 \mathrm{mg} \mathrm{kg}^{-1}\right)$, Cr $\left(0.109 \mathrm{mg} \mathrm{kg}^{-1}\right)$, As $\left(0.344 \mathrm{mg} \mathrm{kg}^{-1}\right)$, and $\mathrm{Pb}\left(0.023 \mathrm{mg} \mathrm{kg}^{-1}\right)$. Furthermore, the comparison of heavy metal contents in this work and the official limits of selected toxicants in foods released by the Thailand Ministry of Public Health in 1986 and 2003 showed that the values found in this work were lower than the limits $\left(\mathrm{Zn}<100 \mathrm{mg} \mathrm{kg}^{-1}, \mathrm{Cu}<20 \mathrm{mg} \mathrm{kg}^{-1}\right.$, and As $\left.<2 \mathrm{mg} \mathrm{kg}^{-1}\right)$. Another interesting result was that $\mathrm{Zn}$ had the highest contents amongst all tested heavy metals. This could be because the soil-to-plant transfer factors (TF) in rice of $\mathrm{Zn}$ was relatively high (0.96), leading to a high transfer

\begin{tabular}{|c|c|c|c|}
\hline Element & Weight of evidence (WOE) characterization ${ }^{a}$ & $R f D\left(\mathrm{mg} \mathrm{kg}^{-1} \mathrm{~d}^{-1}\right)$ & $\operatorname{CSF}\left(\mathrm{mg}^{-1} \mathrm{~kg} \mathrm{~d}\right)$ \\
\hline $\mathrm{Al}$ & $\mathrm{N} / \mathrm{A}$ & $0.286^{b}$ & - \\
\hline $\mathrm{Cr}$ & $\mathrm{N} / \mathrm{A}$ & 0.003 & 0.5 \\
\hline $\mathrm{Fe}$ & $\mathrm{D}$ & 0.8 & - \\
\hline $\mathrm{Cu}$ & $\mathrm{D}$ & $0.5^{\mathrm{b}}$ & - \\
\hline $\mathrm{Zn}$ & N/A & 0.3 & - \\
\hline As & A & 0.0003 & 1.5 \\
\hline $\mathrm{Cd}$ & B1 & 0.001 & 15 \\
\hline $\mathrm{Pb}$ & B2 & $0.0036^{b}$ & 0.91 \\
\hline
\end{tabular}
from soil to plant and a high accumulation of $\mathrm{Zn}$ in rice

anternational Agency for Research on Cancer: group A chemicals are definite human carcinogens; group B1 chemicals are probable human carcinogens based on limited evidence of carcinogenicity in humans; group B2 chemicals are probable human carcinogens based on sufficient evidence of carcinogenicity in animals; and group D chemicals are not classifiable regarding human carcinogenicity. N/A indicates IRIS had inadequate information to assess carcinogenic health risks from oralintake of that element. ${ }^{b} \mathrm{RfD}$ values were not available through IRIS. They were estimated using the PTWI values in Table 1. 
Table 4: $\mathrm{Al}, \mathrm{Cr}, \mathrm{Fe}$, and $\mathrm{Cu}$ contents in raw and cooked rice samples prepared using different rice cookers and water types. Values are represented as mean \pm standard deviation

\begin{tabular}{lcccc}
\hline Samples & \multicolumn{4}{c}{ Content $\left(\mathrm{mg} \mathrm{kg}^{-1}\right)$} \\
\cline { 2 - 5 } Raw Rice & $76.49 \pm 19.72$ & $0.27 \pm 0.03$ & $4.90 \pm 0.42$ & $1.79 \pm 0.26$ \\
New-Al-TW & $76.83 \pm 9.47$ & $0.28 \pm 0.01$ & $4.06 \pm 0.33$ & $1.76 \pm 0.55$ \\
New-Al-DW & $93.37 \pm 8.69$ & $0.31 \pm 0.04$ & $3.95 \pm 0.22$ & $1.91 \pm 0.34$ \\
New-Al-AW & $107.61 \pm 26.16$ & $0.34 \pm 0.09$ & $3.75 \pm 0.55$ & $1.72 \pm 0.65$ \\
New-Al-BW & $62.77 \pm 4.95$ & $0.10 \pm 0.01$ & $4.11 \pm 0.31$ & $1.72 \pm 0.62$ \\
Old-Al-TW & $92.91 \pm 7.35$ & $0.35 \pm 0.01$ & $3.74 \pm 0.46$ & $2.59 \pm 0.25$ \\
Old-Al-DW & $85.04 \pm 13.08$ & $0.68 \pm 0.05$ & $3.81 \pm 1.80$ & $1.78 \pm 1.37$ \\
Old-Al-AW & $44.34 \pm 0.70$ & $0.27 \pm 0.04$ & $2.04 \pm 0.01$ & $1.63 \pm 0.67$ \\
Old-Al-BW & $74.93 \pm 0.02$ & $0.13 \pm 0.02$ & $4.11 \pm 0.70$ & $1.86 \pm 0.19$ \\
Tef-Al-TW & $83.34 \pm 11.31$ & $0.30 \pm 0.03$ & $3.69 \pm 1.48$ & $1.39 \pm 0.17$ \\
Tef-Al-DW & $104.01 \pm 9.89$ & $0.41 \pm 0.01$ & $7.34 \pm 1.06$ & $2.13 \pm 1.16$ \\
Tef-Al-AW & $115.16 \pm 11.41$ & $0.32 \pm 0.03$ & $2.67 \pm 0.18$ & $1.47 \pm 0.91$ \\
Tef-Al-BW & $71.42 \pm 3.11$ & $0.28 \pm 0.05$ & $2.88 \pm 0.77$ & $1.31 \pm 0.72$ \\
SS-TW & $91.85 \pm 4.17$ & $0.34 \pm 0.02$ & $6.48 \pm 0.24$ & $1.66 \pm 0.83$ \\
SS-DW & $84.99 \pm 12.79$ & $0.37 \pm 0.01$ & $2.80 \pm 0.14$ & $1.99 \pm 0.33$ \\
SS-AW & $98.35 \pm 20.85$ & $0.37 \pm 0.04$ & $2.95 \pm 0.18$ & $1.62 \pm 0.47$ \\
SS-BW & $111.03 \pm 15.55$ & $0.25 \pm 0.04$ & $3.15 \pm 0.19$ & $1.76 \pm 0.65$ \\
Gl-TW & $105.21 \pm 11.14$ & $0.44 \pm 0.13$ & $3.22 \pm 1.52$ & $2.21 \pm 0.29$ \\
Gl-DW & $80.78 \pm 14.99$ & $0.14 \pm 0.02$ & $5.69 \pm 0.41$ & $2.23 \pm 0.19$ \\
Gl-AW & $56.00 \pm 9.98$ & $0.15 \pm 0.01$ & $3.09 \pm 0.35$ & $1.58 \pm 0.25$ \\
GI-BW & $49.19 \pm 9.61$ & $0.18 \pm 0.01$ & $4.55 \pm 0.74$ & $1.62 \pm 0.16$ \\
\hline
\end{tabular}

Table 5: $\mathrm{Zn}, \mathrm{As}, \mathrm{Cd}$, and $\mathrm{Pb}$ contents in raw and cooked rice samples prepared using different rice cookers and water types. Values are represented as mean \pm standard deviation

\begin{tabular}{lcccc}
\hline Samples & \multicolumn{4}{c}{ Content $\left(\mathbf{m g ~ k g}^{-1}\right)$} \\
\cline { 2 - 5 } Raw Rice & $22.85 \pm 6.86$ & $0.14 \pm 0.01$ & $0.11 \pm 0.12$ & $1.36 \pm 0.65$ \\
New-Al-TW & $27.58 \pm 7.65$ & $0.15 \pm 0.03$ & $0.24 \pm 0.07$ & $3.83 \pm 0.18$ \\
New-Al-DW & $24.47 \pm 7.65$ & $0.14 \pm 0.02$ & $0.18 \pm 0.03$ & $1.98 \pm 0.16$ \\
New-Al-AW & $24.57 \pm 4.56$ & $0.20 \pm 0.01$ & $0.15 \pm 0.03$ & $2.27 \pm 0.19$ \\
New-Al-BW & $25.83 \pm 1.90$ & $0.16 \pm 0.02$ & $0.16 \pm 0.03$ & $1.76 \pm 0.16$ \\
Old-Al-TW & $26.25 \pm 2.22$ & $0.15 \pm 0.03$ & $0.09 \pm 0.02$ & $1.66 \pm 0.13$ \\
Old-Al-DW & $26.46 \pm 3.00$ & $0.15 \pm 0.04$ & $0.15 \pm 0.03$ & $1.84 \pm 0.05$ \\
Old-Al-AW & $24.57 \pm 1.02$ & $0.19 \pm 0.01$ & $0.15 \pm 0.01$ & $2.30 \pm 0.06$ \\
Old-Al-BW & $23.42 \pm 3.16$ & $0.16 \pm 0.02$ & $0.05 \pm 0.01$ & $1.41 \pm 0.18$ \\
Tef-Al-TW & $22.52 \pm 2.74$ & $0.15 \pm 0.03$ & $0.12 \pm 0.01$ & $1.76 \pm 0.15$ \\
Tef-Al-DW & $26.50 \pm 3.22$ & $0.21 \pm 0.02$ & $0.15 \pm 0.04$ & $2.63 \pm 0.33$ \\
Tef-Al-AW & $24.08 \pm 1.63$ & $0.21 \pm 0.02$ & $0.17 \pm 0.03$ & $2.28 \pm 0.16$ \\
Tef-Al-BW & $26.88 \pm 0.85$ & $0.18 \pm 0.03$ & $0.05 \pm 0.05$ & $1.11 \pm 0.04$ \\
SS-TW & $22.42 \pm 5.77$ & $0.15 \pm 0.01$ & $0.13 \pm 0.04$ & $1.96 \pm 0.26$ \\
SS-DW & $30.61 \pm 3.33$ & $0.20 \pm 0.04$ & $0.20 \pm 0.02$ & $2.66 \pm 0.20$ \\
SS-AW & $31.32 \pm 0.61$ & $0.21 \pm 0.02$ & $0.19 \pm 0.01$ & $2.39 \pm 0.06$ \\
SS-BW & $21.41 \pm 0.56$ & $0.19 \pm 0.01$ & $0.05 \pm 0.01$ & $1.06 \pm 0.04$ \\
Gl-TW & $24.76 \pm 1.25$ & $0.16 \pm 0.06$ & $0.04 \pm 0.01$ & $1.81 \pm 0.12$ \\
GI-DW & $22.94 \pm 5.79$ & $0.17 \pm 0.02$ & $0.03 \pm 0.01$ & $1.82 \pm 0.16$ \\
GI-AW & $26.08 \pm 1.82$ & $0.15 \pm 0.02$ & $0.01 \pm 0.01$ & $1.38 \pm 0.12$ \\
GI-BW & $30.26 \pm 2.38$ & $0.15 \pm 0.03$ & $0.03 \pm 0.01$ & $0.86 \pm 0.06$ \\
\hline & & & &
\end{tabular}

grains. Note that the average $\mathrm{Zn}$ contents in all types of soil in Thailand was reported to be $23.9 \mathrm{mg} \mathrm{kg}^{-1}$, close to the $\mathrm{Zn}$ contents in rice samples (Zarcinas et al. 2004).
In terms of the differences in $\mathrm{Al}$ and heavy metal contents in raw rice samples and cooked rice samples, the results showed that, although there were some fluctuations in values of elemental contents in different rice samples, the t-test at 95\% significant level implied that the values were not significantly different and were statistically inconclusive to draw any conclusion that significant metal leaching was found in this work. The same statistical results that showed insignificant different between rice samples were also found in all conditions. This could be because the variations in rice cooking conditions used in this work might not be sufficient to initiate or to show significant amount of metal leaching as reported by Al Zubaidy et al. (2011) that the leaching of $\mathrm{Al}$ from $\mathrm{Al}$ cookware was dominant when the $\mathrm{pH}$ of the water used in cooking was lower than 3 or higher than 10 , leading to insignificant leaching of metal in rice samples cooked with AW $(\mathrm{pH}=4.0)$ and $\mathrm{BW}(\mathrm{pH}=10.0)$ in this work. Another reason that could also reduce possibility of metal leaching into food during the cooking process was the increase in rice cooker safety standards and also the advances in manufacturing (Underwriters Laboratories Inc., 2017).

Another interesting point to consider was the estimated weekly intake of $\mathrm{Al}$ and heavy metals by rice consumers. Table 6 shows the minimum, maximum, and estimated weekly intake of a person who consumes $0.3 \mathrm{~kg}$ per day of white rice prepared using four types of rice cookers (Old-Al, New-Al, Tef-Al and SS) with TW. The estimated weekly intake for each element was then compared with the PTWI of a person weighing $60 \mathrm{~kg}$. The results showed that the estimated weekly intakes of for $\mathrm{Al}$ and $\mathrm{Pb}$ were higher than PTWI, indicating long-term exposure effects to local consumers. However, the updated PTWI values of $\mathrm{Pb}$ have not yet been issued by the $\mathrm{WHO}$ due to inadequate information to establish health protective levels; hence, reliable conclusions for $\mathrm{Pb}$ cannot be drawn until further information becomes available.

\section{Health risk assessment}

The $A D I, H Q$, and $C R$ values for each heavy metal calculated from the estimated weekly intakes (Table 6) are shown in Table 7.

The $H Q$ values through rice consumption as shown in Table 7 indicate that $\mathrm{Al}, \mathrm{As}$ and $\mathrm{Pb}$ individually posed potential non-carcinogenic risks as their values were greater than 1. Furthermore, the $H I$ value calculated from all metals was 9.18, implying high chronic health risks from rice consumption. The estimated $H I$ was mainly due to the $\mathrm{Pb}$ and As contents, which accounted for $34.7 \%$ and $29.1 \%$ of the $H I$, respectively. The contributions from all concerned metals to the $H I$ value are shown in Fig 1 . In terms of $C R$ and $C R t$ values, $\mathrm{Cd}, \mathrm{Pb}, \mathrm{As}$, and $\mathrm{Cr}$ had $C R$ values greater 
Table 6: Minimum, maximum, estimated weekly intake, and Provisional tolerance weekly intake values of elemental contents in cooked rice samples prepared using four commercial rice cookers and TW. Numbers in parentheses represent PTWI values before the limits were withdrawn

\begin{tabular}{|c|c|c|c|c|}
\hline \multirow[t]{2}{*}{ Element } & \multicolumn{2}{|c|}{ Content $\left(\mathrm{mg} \mathrm{kg}^{-1}\right)$} & \multirow[t]{2}{*}{ Estimated weekly intake $(\mathrm{mg})^{a}$} & \multirow[t]{2}{*}{ Provisional tolerance weekly intake $(\mathrm{mg})^{\mathrm{b}}$} \\
\hline & Minimum & Maximum & & \\
\hline $\mathrm{Al}$ & 76.83 & 92.91 & 181.07 & 120 \\
\hline $\mathrm{Cr}$ & 0.28 & 0.35 & 0.67 & 1.398 \\
\hline $\mathrm{Fe}$ & 3.66 & 6.4 & 9.45 & 336 \\
\hline $\mathrm{Cu}$ & 1.39 & 2.59 & 3.89 & 210 \\
\hline $\mathrm{Zn}$ & 22.42 & 27.55 & 51.87 & $126-420$ \\
\hline As & 0.15 & 0.15 & 0.32 & $(0.882)$ \\
\hline $\mathrm{Cd}$ & 0.09 & 0.24 & 0.32 & 0.36 \\
\hline $\mathrm{Pb}$ & 1.66 & 3.83 & 4.85 & (1.5) \\
\hline
\end{tabular}

${ }^{a}$ For a person who consumes roughly $2.1 \mathrm{~kg}$ of rice per week $(0.3 \mathrm{~kg}$ of rice per day).

${ }^{\mathrm{b}}$ For a person weighing $60 \mathrm{~kg}$

Table 7: Average daily intakes $(A D)$, hazard quotient $(H Q)$, and cancer risk $(C R)$ of metals in cooked rice

\begin{tabular}{lccc}
\hline Element & Average daily intakes; $\boldsymbol{A D I}\left(\mathbf{m g ~ k g}^{-1} \mathbf{d}^{-1}\right)$ & Hazard quotient; $\boldsymbol{H Q}$ & Cancer risk; $C R$ \\
\hline $\mathrm{Al}$ & 0.4311 & 1.51 & - \\
$\mathrm{Cr}$ & 0.0016 & 0.53 & $8.0 \times 10^{-4}$ \\
$\mathrm{Fe}$ & 0.0225 & 0.03 & - \\
$\mathrm{Cu}$ & 0.0093 & 0.02 & - \\
$\mathrm{Zn}$ & 0.1235 & 0.43 & - \\
$\mathrm{As}$ & 0.0008 & 2.67 & $1.7 \times 10^{-3}$ \\
$\mathrm{Cd}$ & 0.0008 & 0.80 & $1.2 \times 10^{-2}$ \\
$\mathrm{~Pb}$ & 0.0115 & 3.19 & $1.0 \times 10^{-2}$ \\
\hline
\end{tabular}

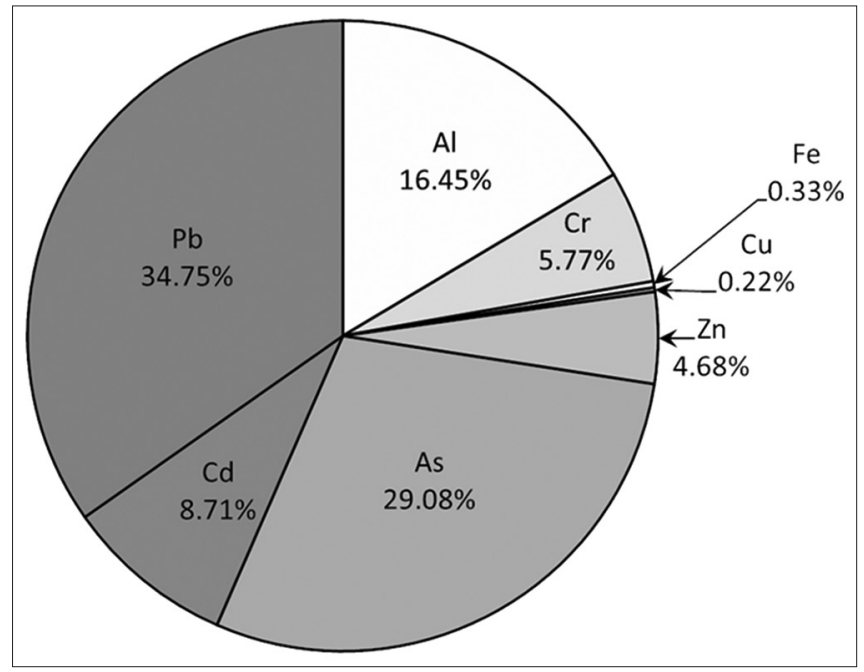

Fig 1. Hazard index (HI) contributed by each metal of interest.

than $10^{-4}$, leading to $C R t$ of $2.45 \times 10^{-2}$, which indicated high carcinogenic risks from rice consumption. Fig 2. shows the contributions of all metals of interest to CRt. These results were similar to reports by Zeng et al. (2015) which indicated that long-term exposure to heavy metals through brown rice consumption posed both potential non-carcinogenic and carcinogenic health risks to the local residents in Hunan Province, China, and by Sinha et al. (2015), which indicated excessive As toxicity in rice with special reference to speciation in Indian grain that led to risks associated with consumption of As contaminated rice.
In summary, rice consumption could pose serious health risks to consumers - through both non-carcinogenic and carcinogenic effects-from $\mathrm{Al}$ and heavy metal contents. Furthermore, when other intake pathways such as inhalation and dermal exposure and other types of foods such as fish, vegetables, and water are taken into consideration, the potential health risks could be greatly increased. Thus, further investigation is needed in order to promote better food safety for consumers.

\section{CONCLUSIONS}

Rice is consumed worldwide and predictions indicate this will continue to increase. However, the health risks from the $\mathrm{Al}$ and heavy metal $(\mathrm{Cr}, \mathrm{Fe}, \mathrm{Cu}, \mathrm{Zn}, \mathrm{As}, \mathrm{Cd}$, and $\mathrm{Pb}$ ) contents in cooked rice have led to serious concerns by consumers. This work used ICP-MS to quantify the contents of $\mathrm{Al}$ and heavy metals in raw/cooked rice samples and to assess potential non-carcinogenic and carcinogenic health risks from rice consumption. The results showed that of the tested metals, $\mathrm{Al}$ and $\mathrm{Zn}$ had the largest contents in raw/cooked rice, while commercial rice cookers, even with the use of acidic $(\mathrm{pH}=4)$ and basic $(\mathrm{pH}=10)$ water, did not leach substantial amounts of the relevant metals into the cooked rice. However, the $\mathrm{Al}$ and $\mathrm{Pb}$ contents in $0.3 \mathrm{~kg}$ of cooked rice consumed daily by a $60 \mathrm{~kg}$ person was greater than the recommended PTWI level issued the $\mathrm{FAO} / \mathrm{WHO}$. Furthermore, $\mathrm{Pb}$, As, and $\mathrm{Al}$ 


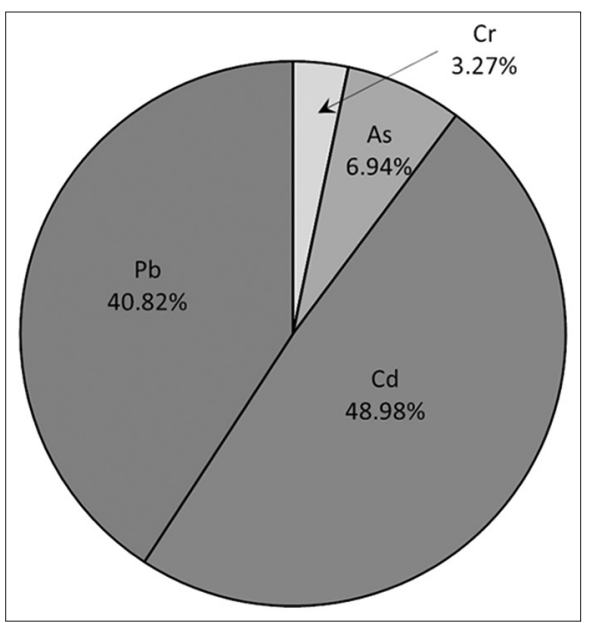

Fig 2. Total cancer risk (CRt) contributed by each metal of interest

contents posed potential non-carcinogenic risks as their $\mathrm{HQ}$ values were greater than 1 , while the $\mathrm{Cd}, \mathrm{Pb}, \mathrm{As}$, and $\mathrm{Cr}$ contents posed carcinogenic risks from rice consumption as their $C R$ values were greater than $10^{-4}$.

\section{ACKNOWLEDGEMENTS}

This work was supported financially by the Kasetsart University Research and Development Institute (KURDI) and the Graduate Program Scholarship from the Graduate School, Kasetsart University, Bangkok, Thailand. We would also like to thank the Department of Disease Control, Ministry of Public Health (Thailand) and the Thailand Institute of Nuclear Technology (Public Organization) for support with equipment and advice.

\section{Author's contributions}

This work is part of the M.Sc. thesis of Anawat Rittirong (AR) advised by Kiadtisak Saenboonruang (KS). AR and KS have designed the study, conducted the experimental work, and analyzed data. KS wrote and revised the manuscript.

\section{REFERENCES}

Al Zubaidy, E. A. H., F. S. Mohammad asnd G. Bassioni. 2011. Effects of $\mathrm{pH}$, salinity and temperature on aluminum cookware leaching during food preparation. Int. J. ELectrochem. Sci. 6: 6424-6441.

Amarasooriya, A. A. G. D. and H. A. Dharmagunawardhane. 2014. Leaching of Aluminum and its Incorporation to Rice During Cooking Under Different Fluoride Concentrations in Water. SAITM Research Symposium on Engineering Advancements 2014. Sri Lanka.

Becaria, A., D. K. Lahiri, S. C. Bondy, D. Chen, A. Hamadeh, H. Li, R. Taylor and A. Campbell. 2006. Aluminum and copper in drinking water enhance inflammatory or oxidative events specifically in the brain. J. Neuroim. 176(1-2): 16-23.

Cao, S., X. Duan, X. Zhao, B. Wang, J. Ma, D. Fan, C. Sun, B. He,
F. Wei and G. Jiang. 2015. Health risk assessment of various metal(loids) via multiple exposure pathways on children living near a typical lead-acid battery plant, China. Environ. Pollut. 200: 16-23.

Center for Food Safety. 2009. Risk Assessment Studies Report No. 35: Chemical Hazard Evaluation: Aluminum in Food. The Government of the Hong Kong Special Administrative Region, Hong Kong.

Charoensitiwath, S. 2010. SizeThailand e-Health: A Personalised Health Monitoring and Diagnosis System using 3D Body Scanning Technology. Portland International Conference on Management of Engineering and Technology (PICMET '10), 18 - 22 July 2010, Phuket, Thailand.

Crapper, D. R., S. S. Krishnan and A. J. Dalton. 1966. Brain aluminum distribution in Alzheimer's disease and experimental neutronfibrillary degeneration. Science. 180: 511-513.

Flaten, T. P. 2001. Aluminum as a rich factor in Alzheimer's disease, with emphasis on drinking water. Brain Res. Bull. 55: 187-196.

Horn, I., R. L. Rudnick and W. F. McDonough. 2000. Precise elemental and isotope ratio determination by simultaneous solution nebulization and laser ablation-ICP-MS: application to U-Pb geochronology. Chem. Geol. 164: 281-301.

Ileperuma, O. A., H. A. Dharmagunawardhane and K. P. R. P. Herath. 2009. Dissolution of aluminium from sub-standard utensils under high fluoride stress: A possible risk factor for chronic renal failure in the North-Central Province. J. Natn. Sci. Foundation Sri Lanka. 37(3): 219-222.

Integrated Risk Information System. Available from: https://www.epa. gov/iris. [Last accessed on 2017 Apr 03].

Kamerud, K. L., K. A. Hobbie and K. A. Anderson. 2013. stainless steel leaches nickel and chromium into foods during cooking. J. Agric. Food Chem. 61: 9495-9501.

McLachlan, D. R. C., C. Bergeron, J. E. Smith, D. Boomer and S. L. Rifat. 1996. Risk for neuropathologicallly confirmed Alzheimer's disease and residual aluminum in municipal drinking water employing weighted residential histories. Neurology. 335: 1037.

Mohanty, S. 2013. Trends in global rice consumption. Available from: http://www.irri.org/rice-today/trends-in-global-rice-consumption. [Last accessed on 2017 Jan 06].

Nuapia, Y., L. Chimuka and E. Cukrowska. 2018. Assessment of heavy metals in raw food samples from open markets in two African cities. Chemosphere. 196: 339-346.

Occupational Safety and Health Administration. 2013. Safety and Health Topics. United States Department of Labor, Washington, DC.

Odularu, A. T., P. A. Ajibade and P. C. Onianwa. 2013. Comparative study of leaching of aluminium from aluminium, clay, stainless steel, and steel cooking pots. Public Health. 2013: 517601.

Omar, N. A., S. M. Praveena, A. Z. Aris and Z. Hashim. 2015. Health risk assessment using in vitro digestion model in assessing bioavailability of heavy metal in rice: A preliminary study. Food. Chem. 188: 45-50.

Sinha, B. and K. Bhattacharyya. 2015. Arsenic toxicity in rice with special reference to speciation in Indian grain and its implication on human health. J. Sci. Food. Agric. 95: 1435-1444.

Semwal, A., A. Padmashree, M. A. Khan, G. K. Sharma and A. S. Bawa. 2006. Leaching of aluminium from utensils during cooking of food. J. Sci. Food. Agric. 86: 2425-2430.

Underwriters Laboratories Inc. 2017. UL 1026 Electric household cooking and food serving appliances. Available from: http:// www.ulstandards.ul.com/standard/?id=1026_6. [Last accessed on 2017 Apr 05].

Whitea, W. M., F. Albaredeb and P. Teloukb. 2000. High-precision 
analysis of $\mathrm{Pb}$ isotope ratios by multi-collector ICP-MS. Chem. Geol. 167: 257-270.

World Health Organization. 1989. FAO/WHO Expert Committee Report on Food Additives: 33rd Report. WHO Technical Report Series. World Health Organization, Geneva.

World Health Organization. 2011. FAO/WHO Expert Committee Report on Food Additives: 47rd Report. WHO Technical Report Series. World Health Organization, Geneva.

World Health Organization. 2015. Thailand Statistics. Available from: http://www.who.int/countries/tha/en. [Last accessed on 2018 Apr 05].

Zarcinas, B. A, P. Pongsakul, M. J. McLaughlin and G. Cozens. 2004. Heavy metals in soil and crops in Southeast Asia. 2. Thailand. Environ. Geochem. Health. 26: 359-371.

Zeng, F., W. Wei, M. Li, R. Huang, F. Yang and Y. Duan. 2015. Heavy metal contamination in rice-producing soils of Hunan province, China and potential health risks. Int. J. Environ. Res. Public. Health. 12(12): 15584-15593. 